\title{
Induction and partial purification of bacteriophages from Desulfovibrio vulgaris (Hildenborough) and Desulfovibrio desulfuricans ATCC 13541
}

\author{
S. SeYedirashti, C. Wood and J. M. AKaGi* \\ Department of Microbiology, 7042 Haworth Hall, University of Kansas, Lawrence, KS 66045, USA
}

(Received 5 February 1991; revised 1 March 1991; accepted 18 March 1991)

\begin{abstract}
Bacteriophages were induced from cultures of Desulfovibrio vulgaris NCIMB 8303 and Desulfovibrio desulfuricans ATCC 13541 by UV light. The optimum time of UV exposure was $1 \mathrm{~min}$ and the maximum yield of phage was obtained 9-10 h after UV treatment. The two phage preparations were compared by restriction enzyme analysis and Southern blot hybridization. The nucleic acid from both phages was cut by restriction endonucleases specific for double-stranded DNA. The phage DNAs from $D$. vulgaris and $D$. desulfuricans showed different restriction enzyme cleavage patterns. No homology was observed between a $25 \mathrm{~kb}$ probe from the $D$. vulgaris phage DNA and the phage DNA from $D$. desulfuricans. Protein profiles of the phages from both sources were also studied; the $D$. vulgaris phage contained two major bands corresponding to $M_{\mathrm{r}}$ values of 37000 and 56000 while the $D$. desulfuricans phage contained only one major band, of $M_{\mathrm{r}} 38000$.
\end{abstract}

\section{Introduction}

The biochemistry of dissimilatory sulphate reduction by sulphate-reducing bacteria has been extensively investigated over the past three decades. Enzymes and electrontransport agents participating in the overall process of sulphate reduction to sulphide have been isolated and purified and the amino acid sequences of several of these proteins have been determined (Ambler et al., 1971; Bruschi \& LeGall, 1976; Bruschi et al., 1979; Dubourdieu et al., 1973; Travis et al., 1971). In contrast, little information is available concerning the genetics of and genetic exchanges occurring among sulphate-reducing bacteria; this is due, in part to the difficulty in culturing these fastidious and unpredictable micro-organisms on solid media for performing genetic analyses. With advances in recombinant DNA technology, several molecular genetic approaches have been used to study the sulphate-reducing bacteria. However, due to the lack of characterized vectors, such as plasmids and bacteriophages, that can be used to mediate genetic transfer, molecular studies on these organisms have been limited to cloning and expression of bacterial genes, such as those coding for cytochrome $c_{3}$ and hydrogenase (Fons $e t$ al., 1987; Li et al., 1986; Menon et al., 1987; Pollock et al., 1991 ; van Rooijen et al., 1989; Voordouw \& Brenner, 1985, 1986; Voordouw et al., 1985, 1989a, b).
Earlier work from this laboratory showed that phagelike particles were induced from cultures of Desulfovibrio vulgaris by mitomycin C or UV light treatment (Handley et al., 1973). Postgate et al. (1984) reported the occurrence of plasmids in several species and strains of sulphate-reducing bacteria. More recently, Rapp \& Wall (1987) described the isolation of phages from Desulfovibrio desulfuricans ATCC 27774 and demonstrated that these phages were involved in gene transfer by a generalized transduction process. These observations strongly suggest that genetic exchange among sulphatereducing bacteria is possible, and open the way for significant advances in understanding the genetic makeup of these organisms. Thus, a detailed characterization of phages from sulphate-reducing bacteria, and studying their possible application as vectors for genetic transfer, would be valuable in understanding the molecular genetics of these bacteria.

As part of our overall programme to investigate the molecular biology and genetics of sulphate-reducing bacteria, we reinvestigated the induction of phage from D. vulgaris to (i) elucidate the parameters for obtaining high yields of phage particles, (ii) characterize the phage nucleic acid by restriction enzyme analysis, and (iii) obtain a protein profile of the phage. For comparative purposes we also succeeded in inducing a phage from $D$. desulfuricans ATCC 13541 ('Vibro cholinicus') (Postgate 
\& Campbell, 1966) and determined the differences in the DNA restriction enzyme pattern between the phages obtained from both organisms.

\section{Methods}

Growth of organisms. The organisms used in this study were Desulfovibrio vulgaris Hildenborough (NCIMB 8303) and Desulfovibrio desulfuricans (ATCC 13541), which was obtained from the American Type Culture Collection. Both strains were grown in medium C (Postgate, 1984) at $37^{\circ} \mathrm{C}$; Escherichia coli and Salmonella typhimurium were grown at $37^{\circ} \mathrm{C}$ in Luria broth supplemented with $0.1 \%$ glucose and $10 \mathrm{~mm}-\mathrm{MgSO}_{4}$. All cultures were periodically checked for purity.

Induction of phages. Portions $(120 \mathrm{ml})$ of $8 \mathrm{~h}$ old cultures were irradiated for 1 min with UV light in a $30 \times 20.5 \mathrm{~cm}$ pan with gentle agitation. The UV source was a $15 \mathrm{~W}$ General Electric Germicidal lamp. The dosage at a distance of $40 \mathrm{~cm}$ was $0.8 \mathrm{~J} \mathrm{~m}^{-2} \mathrm{~s}^{-1}$. After exposure to UV, the cultures were incubated anaerobically for various lengths of time $(0-96 \mathrm{~h})$.

Purification of phage particles and extraction of DNA. Concentration of phages and extraction of DNA were performed by a modification of the procedure of Maniatis et al. (1982). Briefly, induced cultures were centrifuged at $5000 \mathrm{~g}$ for $30 \mathrm{~min}$. The supernatant fraction was treated with RNAase A and DNAase I, each at a final concentration of $1 \mu \mathrm{g}$ $\mathrm{ml}^{-1}$, and incubated at $37^{\circ} \mathrm{C}$ for $30 \mathrm{~min}$. Polyethylene glycol and $\mathrm{NaCl}$ were added at final concentrations of $10 \%(\mathrm{w} / \mathrm{v})$ and $1 \mathrm{M}$, respectively, and the mixture was stored at $4{ }^{\circ} \mathrm{C}$ overnight. The precipitated phage particles were sedimented at $10000 \mathrm{~g}$ for $20 \mathrm{~min}$ and suspended in $1 \mathrm{ml}$ TM buffer ( $10 \mathrm{mM}$-Tris/HCl buffer, $\mathrm{pH} 8.0$, containing $10 \mathrm{~mm}$ $\mathrm{MgSO}_{4}$ ). For quantification of phage DNA yield, phage DNA was extracted by the addition of SDS and EDTA at final concentrations of $1 \%(\mathrm{w} / \mathrm{v})$ and $10 \mathrm{~mm}$, respectively, followed by extraction with phenol/chloroform $(1: 1, \mathrm{v} / \mathrm{v})$ and dialysis against TE buffer $(10 \mathrm{mM}$ Tris/ $\mathrm{HCl}$ buffer, $\mathrm{pH} 7.6$, containing $1 \mathrm{mM}$-EDTA). Absorbance was measured at 260 and $280 \mathrm{~nm}$ with a Beckman DU-40 spectrophotometer.

For large-scale preparations, phages were purified using a three-step $\mathrm{CsCl}$ gradient $\left(1.3,1.5,1.7 \mathrm{~g} \mathrm{ml}^{-1}\right)$ prior to extraction of DNA. The gradient was centrifuged at 37000 r.p.m. in a Beckman SW-41 rotor for $1.5 \mathrm{~h}$ at $18{ }^{\circ} \mathrm{C}$ in a Beckman L2-65B ultracentrifuge. The phage band was collected, dialysed against TM buffer, and stored at $4{ }^{\circ} \mathrm{C}$. Phage DNA was extracted as described above and was purified by centrifugation (45000 r.p.m., Beckman 50Ti rotor, L2-65B ultracentrifuge) for $36 \mathrm{~h}$ at $18^{\circ} \mathrm{C}$ in $\mathrm{CsCl}\left(1.5 \mathrm{~g} \mathrm{ml}^{-1}\right)$ solution containing $125 \mu \mathrm{g}$ ethidium bromide $\mathrm{ml}^{-1}$. The DNA band was collected with a syringe and needle and the ethidium bromide was extracted with isoamyl alcohol saturated with $\mathrm{CsCl}$. The DNA preparation was dialysed against TE buffer overnight and stored at $4{ }^{\circ} \mathrm{C}$.

Restriction endonuclease analyses. Phage DNA was digested with restriction endonucleases purchased from New England Biolabs and used as recommended by the manufacturer. Digestions were performed for $2 \mathrm{~h}$ at $37^{\circ} \mathrm{C}$ using 3 units of enzyme per $\mu \mathrm{g}$ of DNA. Restriction enzyme patterns on gels were recorded using Polaroid type 667 film.

Molecular cloning. Phage DNA from D. vulgaris was digested with HindIII and DNA fragments were ligated to the HindIII site of the cosmid vector PJB8 (Ish-Horowicz \& Burke 1981). The resulting recombinant cosmids were packaged in vitro according to Ish-Horowicz $\&$ Burke (1981) and used to infect $E$. coli 803. Infected cells were plated on LB agar plates containing $100 \mu \mathrm{g}$ ampicillin $\mathrm{ml}^{-1}$ (Maniatis et al., 1982).
Southern blot hybridization. Phage DNAs, either uncut or cut with restriction enzymes, were subjected to electrophoresis in $0.7 \%$ agarose gels. Phage DNAs were depurinated by immersion of the gel in $0.1 \mathrm{M}$ $\mathrm{HCl}$ for $15 \mathrm{~min}$ at room temperature followed by immersion in $0.5 \mathrm{M}-$ $\mathrm{NaOH}$, containing $1.5 \mathrm{M}-\mathrm{NaCl}$, at the same temperature for $15 \mathrm{~min}$. The gel was neutralized with $0.5 \mathrm{M}-\mathrm{Tris} / \mathrm{HCl}$ buffer, $\mathrm{pH} 7 \cdot 5$, containing $3 \mathrm{M}-\mathrm{NaCl}$. The DNA was subsequently transferred to nitrocellulose filter paper (Schleicher and Schuell) by capillary blotting for $16 \mathrm{~h}$ in $20 \times$ SSC (Southern, 1975), followed by baking in a vacuum oven for $2 \mathrm{~h}$ at $80^{\circ} \mathrm{C}$. The nitrocellulose paper was soaked at $42^{\circ} \mathrm{C}$ in a solution consisting of $50 \%(\mathrm{v} / \mathrm{v})$ deionized formamide, $5 \times \mathrm{SSC}, 0.1 \% \mathrm{BSA}$, $0.1 \%$ polyvinylpyrrolidone, $0.1 \%$ Ficoll, $1 \%(\mathrm{w} / \mathrm{v})$ glycine, $50 \mathrm{~mm}-$ sodium phosphate buffer, $\mathrm{pH} 6.5$, and $250 \mu \mathrm{g}$ denatured salmon sperm DNA ml-1. The probe DNA was labelled with $\left[\alpha^{-32} \mathrm{P}\right] \mathrm{dATP} ; 5 \times 10^{6}$ c.p.m. were used for hybridization studies. These were performed at $42{ }^{\circ} \mathrm{C}$ for $16 \mathrm{~h}$ with the phage DNA on nitrocellulose paper immersed in a solution containing $50 \%(\mathrm{v} / \mathrm{v})$ deionized formamide, $5 \times \mathrm{SSC}$, $0.02 \%$ BSA, $0.2 \%$ polyvinylpyrrolidone, $0.02 \%$ Ficoll, 20 mM-sodium phosphate buffer, $\mathrm{pH} 6 \cdot 5,10 \%$ dextran sulphate, and $50 \mu \mathrm{g}$ denatured salmon sperm DNA ml-1. The filter paper was washed successively in $2 \times$ SSC containing $0.1 \%$ SDS, and $0.2 \%$ SSC containing $0.1 \%$ SDS, for $15 \mathrm{~min}$ each at $42^{\circ} \mathrm{C}$. Autoradiography was performed at $-70{ }^{\circ} \mathrm{C}$ on Dupont Cronex film using a Lightning Plus intensifying screen (Dupont).

SDS-PAGE of phage proteins. Structural proteins from both phages, together with low molecular weight standards (Bio-Rad) were separated by electrophoresis on $12.5 \%(\mathrm{w} / \mathrm{v})$ denaturing SDSpolyacrylamide gels. Samples to be run were boiled in $50 \mu \mathrm{l} \mathrm{Laemmli}$ sample buffer with 2-mercaptoethanol according to Laemmli (1970). After cooling, the samples were loaded on the gel. After the run, the gel was fixed and stained with $0 \cdot 125 \%$ Coomassie Brilliant Blue R-250.

Chemicals. Mitomycin C, Coomassie Brilliant Blue R-250, ethidium bromide, Ficoll, polyvinylpyrrolidone, salmon sperm DNA and $[\alpha-$ $\left.{ }^{32} \mathrm{P}\right] \mathrm{dATP}$ were purchased from Sigma. Restriction enzymes were obtained from Pharmacia Fine Chemicals and New England Biolabs.

\section{Results}

\section{UV induction studies}

Handley et al. (1973) reported that phage-like particles could be induced from $D$. vulgaris by mitomycin $C$ or UVtreatment. In our hands the yield of phage induced by mitomycin $\mathrm{C}$ treatment $\left(2.5 \mu \mathrm{g} \mathrm{ml}^{-1}\right.$ for $\left.15 \mathrm{~h}\right)$ according to Handley et al. (1973) was consistently lower that that observed for UV irradiation. Since it was important that the maximum yield of phage was obtained, we chose the latter for phage induction in this study. The UV exposure time for maximum phage production, as indicated by the amount of DNA recovered, was determined to be 60 $90 \mathrm{~s}$. Phage DNA was quantified by absorbance measurements at $260 \mathrm{~nm}$. To determine the optimal incubation time after induction, cultures were UV irradiated for $1 \mathrm{~min}$ and harvested at various times (Fig. 1). In both uninduced and induced cultures we observed phage liberation in small quantities ( $7 \mu \mathrm{g}$ per $240 \mathrm{ml}$ of culture) for up to $6 \mathrm{~h}$ after UV irradiation. This indicated that some spontaneous lysis of cells was occurring. However, 


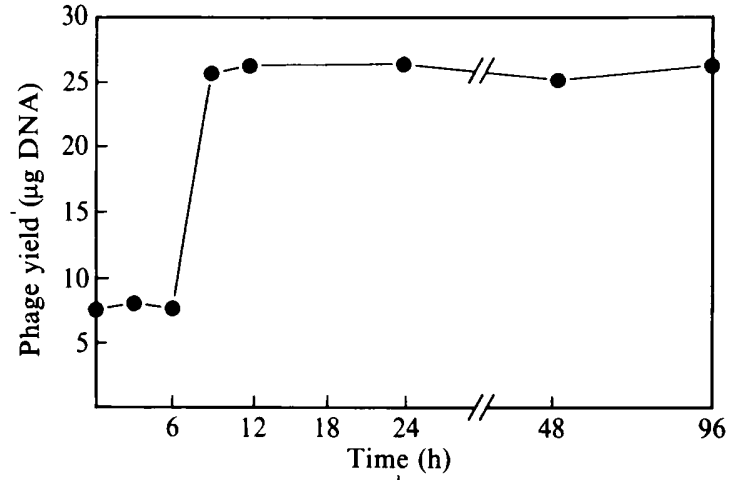

Fig. 1. Effect of time on D. vulgaris phage yield. Cultures $8 \mathrm{~h}$ old were exposed to UV for $1 \mathrm{~min}$ and harvested at the indicated times. Phage DNA was extracted and quantified as described in the text.

a sudden increase in phage yield was observed $(25 \mu \mathrm{g}$ per $240 \mathrm{ml}$ culture) $9-10 \mathrm{~h}$ after irradiation and the phage titre then remained constant for up to $96 \mathrm{~h}$.

\section{Preliminary characterization of the phage nucleic acids from D. vulgaris and D. desulfuricans}

The nucleic acid from both phages was easily cut by double-stranded-DNA-specific restriction endonu- cleases, indicating that the genomes consisted of doublestranded DNA. Fig. 2(a) shows the comparative restriction enzyme patterns of phage DNA from $D$. vulgaris and $D$. desulfuricans. The various restriction enzymes tested cut DNA from both phages, but their patterns were significantly different. This indicated that the genomes of these phages share no gross homology. In the case of $D$. vulgaris, a large HindIII fragment is seen (lane D) above the $23 \mathrm{~kb}$ marker resulting from $\lambda$ DNA digested with HindIII (lanes A and N). This fragment was cloned into a cosmid and was estimated to be approximately $25 \mathrm{~kb}$ in size (data not shown). In addition to this fragment, bands of 13.5 and $1.8 \mathrm{~kb}$ in size are seen. Based on the various restriction patterns the $D$. vulgaris phage genome was estimated to be at least $40 \cdot 3 \mathrm{~kb}$. $D$. desulfuricans phage DNA was also cut by $H$ indIII into several fragments ranging from 13.1 to $2.9 \mathrm{~kb}$ and its genome was estimated to be approximately $45 \mathrm{~kb}$ in size. EcoRI and BamHI also digested $D$. desulfuricans phage DNA extensively; however, these enzymes only partially digested $D$. vulgaris phage DNA, as some uncut DNA can be seen. Other enzymes such as ClaI cut the D. vulgaris phage DNA but did not appear to cut the DNA from the $D$. desulfuricans phage.

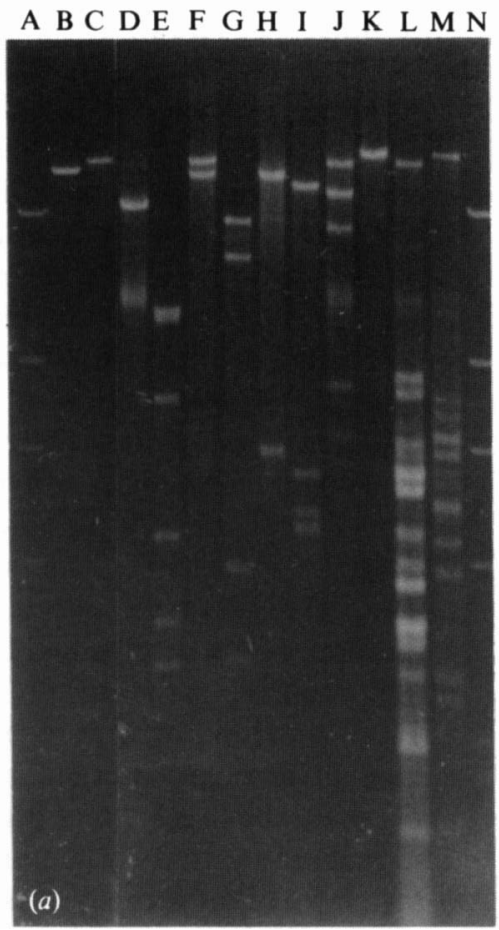

Fig. 2. Restriction endonuclease patterns of phage DNA from D. vulgaris NCIMB 8303 and D. desulfuricans ATCC 13541. (a) Lanes A and $N, \lambda$ phage DNA digested with HindIII. Uncut DNAs from D. vulgaris and D. desulfuricans are shown in lanes B and C, respectively. The patterns for D. vulgaris phage DNA using HindIII, EcoRI, BamHI, ClaI and AvaI are shown in lanes D, F, H, J and L. The patterns for the phage from $D$. desulfuricans using the same enzymes are shown in lanes E, G, I, K and M. (b) Autoradiogram of a Southern blot of the DNA in $(a)$ using a ${ }^{32} \mathrm{P}$-labelled $25 \mathrm{~kb}$ probe from $D$. vulgaris phage DNA. 


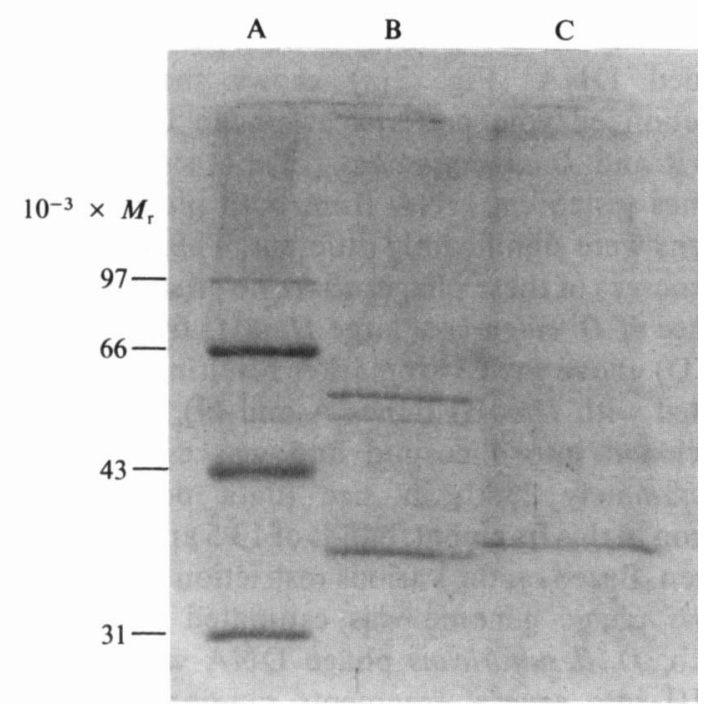

Fig. 3. SDS-PAGE analysis of phage protein profiles. Lane A, $M_{\mathrm{r}}$ standards; lane B, proteins from $D$. vulgaris phage; lane $C$, proteins from $D$. desulfuricans phage.

\section{Hybridization of D. vulgaris and D. desulfuricans phage} $D N A$

Phage DNA from D. vulgaris was digested with HindIII and the fragments were subcloned into the $E$. coli cosmid vector PJB8. One subclone contained a $25 \mathrm{~kb}$ phage insert and this was used to check for cross-hybridization between the phage DNAs from $D$. vulgaris and $D$. desulfuricans. The autoradiogram of the Southern blot is shown in Fig. 2(b). The $25 \mathrm{~kb}$ nick-translated probe from $D$. vulgaris phage DNA hybridized with itself as expected, but did not hybridize with the phage DNA from $D$. desulfuricans. These results clearly indicated that the phages from the two organisms were different and shared no DNA sequence homology.

\section{Protein profile of the phage particles}

Large quantities of the phages from both organisms were harvested and intact particles were obtained by caesium chloride gradient centrifugation. The protein profiles of the phages were analysed by SDS-PAGE (Fig. 3). Two major and six minor bands were obtained from the phage particles from $D$. vulgaris. The minor bands were very faint. The $M_{\mathrm{r}}$ values of the minor species were calculated to be approximately $38000,40000,44000,48000$ and 50000 , with one being above 97000 ; the major bands had $M_{\mathrm{r}}$ values of 37000 and 56000 . In the phage of $D$. desulfuricans, only one major and eight minor bands were detected. The major band was calculated to have an $M_{\mathrm{r}}$ of approximately 38000 , while those of the minor bands ranged from 42000 to over 97000 .

\section{Discussion}

Both D. vulgaris NCIMB 8303 and D. desulfuricans ATCC 13541 are lysogenic. However, the phages that were induced from these two organisms were quite distinct from each other as judged by restriction endonuclease patterns. Furthermore, the lack of hybridization between the $D$. vulgaris and $D$. desulfuricans phages, using a labelled $D$. vulgaris phage DNA fragment as probe (Fig. $2 b$ ), implies that the two phages may not have common ancestries.

In our restriction analyses of the phage DNA, a complete digest was not obtained, especially with some enzymes such as $A v a I$ and $B g l \mathrm{II}$. This incomplete digestion may imply some unique properties of the phage DNA, such as the presence of unusual bases and/or strong association with protein or polysaccharide that could not be dissociated under standard conditions of nucleic acid purification, or a low frequency of the specific sequences recognized by these enzymes.

The protein profiles of the phage particles showed conspicuous differences in number and size of their major bands. The two major bands from the structural proteins of the $D$. vulgaris phage, of $M_{\mathrm{r}} 37000$ and 56000 , corresponded to the two major structural protein bands observed in a bacteriophage lytic for Desulfovibrio salexigens, a halophilic sulphate-reducing bacterium (Kamimura \& Araki, 1989). If the structural proteins from $D$. vulgaris phage are similar to those reported for $D$. salexigens phage, the $M_{\mathrm{r}} 37000$ protein in this study should correspond to the head while the $M_{\mathrm{r}} 56000$ protein band represents the tail protein. This would be in agreement with our finding that the phage from $D$. desulfuricans showed only one major protein band, of $M_{\mathrm{r}}$ 38000 . This protein presumably corresponds to the head protein of the phage; no major tail protein band was observed in the $M_{\mathrm{r}}$ region of 56000 , probably because this phage has a short tail (unpublished observations).

The major difficulty in studying the properties of these phages is the lack of a suitable indicator strain. The $D$. vulgaris NCIMB 8303 phage was not able to grow on $E$. coli or Salmonella typhimurium, as determined by plaque formation, or, as determined by phage DNA detection, on D. desulfuricans strains ATCC 13541 and NCIMB 8310. Compounding this problem is the difficulty of culturing these micro-organisms on solid media, especially to establish a lawn of organisms to detect plaques. The technique used by Kamimura \& Araki (1989) to form a lawn of these organisms may be the answer to this problem. We are currently concentrating on the phage from $D$. vulgaris because much of the biochemistry and physiology of this organism is already known. Although the phage from $D$. vulgaris was induced from a pure culture, we have not eliminated the possibility that more 
than one type of phage was induced since it was not possible to purify the phage by the plaque assay method. We have initiated the subcloning of several restriction enzyme fragments of $D$. vulgaris phage DNA into E. coli using cosmid vectors, and are in the process of elucidating the physical map of this phage DNA.

This study was supported, in part, by a grant, AI-24115 (to C.W.) from the National Institute of Allergy and Infectious Diseases, by a grant from the University of Kansas General Research Fund, and from a Biomedical Sciences Support grant.

\section{References}

Ambler, R. P., Bruschi, M. \& LeGall, J. (1971). The amino acid sequence of cytochrome $c_{3}$ from Desulfovibrio desulfuricans (strain E1 Agheila Z, NCIB 8380). FEMS Letters 18, 347-350.

BRADLEY, D. E. (1967). Ultrastructure of bacteriophages and bacteriocins. Bacteriological Reviews 31, 230-314.

BRusChi, M. \& LeGall, J. (1976). Structural studies of electron transfer proteins from sulfate reducing bacteria: the amino acid sequence of two rubredoxins isolated from D. vulgaris and D. gigas. In Iron and Copper Proteins, pp. 57-67. Edited by K. T. Yasunobu, H. F. Mower \& O. Hayaishi. New York: Plenum Publishing Corporation.

Bruschi, M., Moura, I., LeGall, J., Xavier, A. V. \& Sieker, L. C. (1979). The amino acid sequence of desulforedoxin, a new type of non-heme iron protein from Desulfovibrio gigas. Biochemical and Biophysical Research Communications 90, 596-605.

Dubourdieu, M., LeGall, J \& Fox, J. L. (1973). The amino-acid sequence of Desulfovibrio vulgaris flavodoxin. Biochemical and Biophysical Research Communications 52, 452-458.

Fons, M., Cami, B., Patte, J.-C. \& Chippaux, M. (1987). Cloning in Escherichia coli of genes involved in the synthesis of proline and leucine in Desulfovibrio desulfuricans Norway. Molecular and General Genetics 206, 141-143.

Handley, J., Adams, V. \& AKagl, J. M. (1973). Morphology of bacteriophage-like particles from Desulfovibrio vulgaris. Journal of Bacteriology 115, 1205-1207.

IsH-Horowicz, D. \& BURKE, J. F. (1981). Rapid and efficient cosmid cloning. Nucleic Acids Research 9, 2989-2998.

KAMIMURA, K. \& ARAKI, M. (1989). Isolation and characterization of a bacteriophage lytic for Desulfovibrio salexigens, a salt-requiring sulfate-reducing bacterium. Applied and Environmental Microbiology 55, 645-648.

LAEMmLI, U. K. (1970). Cleavage of structural protein during the assembly of the head of bacteriophage T4. Nature, London 227, 680-685.

Li, C., Peck, H. D. \& Przybla, A. E. (1986). Complementation of an Escherichia coli pyrF mutant with DNA and Desulfovibrio vulgaris. Journal of Bacteriology 165, 644-646.
Maniatis, T., Fritsch, E. F. \& Sambrook, J. (1982). Molecular Cloning: A Laboratory Manual. Cold Spring Harbor, NY: Cold Spring Harbor Laboratory.

MATTHEWS, R. E. F. (1982). Classification and nomenclature of viruses. Intervirology 17, 1-199.

Menon, N. K., Peck, H. D., Legall, J. \& Przybla, A. E. (1987) Cloning and sequencing of the gene encoding the large and small subunits of the periplasmic ( $\mathrm{NiFeSe}$ ) hydrogenase of Desulfovibrio baculatus. Journal of Bacteriology 169, 5401-5407.

Pollock, W. B. R., Louti, M., BRUSCHI, M., RAPP-Gilles, B., Wall, J. D. \& VooRdouw, G. (1991). Cloning, sequencing, and expression of the gene encoding the high-molecular-weight cytochrome $c$ from Desulfovibrio vulgaris Hildenborough. Journal of Bacteriology 173, 220-228.

Postgate, J. R. (1984). The Sulphate-reducing Bacteria, 2nd edn. Cambridge: Cambridge University Press.

Postgate, J. R. \& Campbell, L. L. (1966). Classification of Desulfovibrio species, the nonsporulating sulfate-reducing bacteria. Bacteriological Reviews 30, 732-738.

Postgate, J. R., Kent, H. M., Robson, R. L. \& Chesshyre, J. A. (1984). The genomes of Desulfovibrio gigas and D. vulgaris. Journal of General Microbiology 130, 1597-1601.

RAPP, B. J. \& WaLL, J. D. (1987). Genetic transfer in Desulfovibrio desulfuricans. Proceedings of the National Academy of Sciences of the United States of America 84, 9128-9130.

VAN Rooijen, G. J. H., BrusChI, M. \& Voordouw, G. (1989). Cloning and sequencing of the gene encoding cytochrome $c_{553}$ from Desulfovibrio vulgaris Hildenborough. Journal of Bacteriology 171, 3575-3578.

SouTHERN, E. M. (1975). Detection of specific sequences among DNA fragments separated by gel electrophoresis. Journal of Molecular Biology 98, 503-517.

Travis, J., Newman, D. J., LeGall, J. \& Peck, H. D. (1971). The amino-acid sequence of ferredoxin from the sulfate reducing bacterium D. gigas. Biochemical and Biophysical Research Communications 45, 452-458.

VOORDOUW, G. \& BrenNer, S. (1985). Nucleotide sequencing of the gene encoding the hydrogenase from Desulfovibrio vulgaris (Hildenborough). European Journal of Biochemistry 148, 515-520.

VoORDOUW, G. \& BRENNER, S. (1986). Cloning and sequencing of the gene encoding cytochrome $c_{3}$ from Desulfovibrio vulgaris (Hildenborough). European Journal of Biochemistry 159, 347-351.

Voordouw, G., Walker, J. E. \& Brenner, S. (1985). Cloning of the gene encoding the hydrogenase from Desulfovibrio vulgaris (Hildenborough) and determination of the $\mathrm{NH}_{2}$-terminal sequence. European Journal of Biochemistry 148, 509-514.

Voordouw, G., Menon, N. K., LeGall, J., Choi, E-S., PeCK, H. D. \& PrzYbla, A. E. (1989a). Analysis and comparison of nucleotide sequences encoding the genes for ( $\mathrm{NiFe})$ and $(\mathrm{NiFeSe})$ hydrogenases from Desulfovibrio gigas and Desulfovibrio baculatus. Journal of Bacteriology 171, 2894-2899.

Voordouw, G., Strang, J. D. \& Wilson, F. R. (1989b). Organization of the genes encoding $(\mathrm{Fe})$ hydrogenase in Desulfovibrio vulgaris subsp. oxamicus Monticello. Journal of Bacteriology 171, 3881-3889. 